\title{
A CERÂmica de COZinha AFricana de Monte Molião (Lagos, Portugal) E o SEU ENQUAdRAMENTO RegionaL ${ }^{1}$
}

The african cooking ware from Monte Molião (Lagos, Portugal) in the regional contetx

Ana Margarida Arruda

Álvaro Pereira

Universidade de Lisboa

Recibido: 24/10/2016

Revisado: 16/02/2017
Aceptado: $19 / 05 / 2017$

Publicado: 23/06/2017

\section{RESUMO}

O conjunto de cerâmica de cozinha africana de Monte Molião é composto por 2005 fragmentos classificáveis, apesar de apenas 1767 serem passíveis de tipificação (de acordo com as propostas de Tortorella, Hayes e Bonifay). As peças foram analisadas de acordo com a sua posição estratigráfica, o que permitiu retirar informação sobre a sua cronologia absoluta e integração nas diferentes fases de ocupação romana do sítio.

O circuito da cerâmica de cozinha africana no sul de Portugal foi proposto com base nos dados do sítio de Lagos, mas também em outros provenientes de distintos locais algarvios, tendo-se concluído que aqueles em que esta cerâmica se tinha registado eram litorais ou facilmente acessíveis por rio.

\section{ABSTRACT}

The set of African cooking ware from Monte Molião encompasses 2005 classifiable fragments, but only 1767 were typified (according to the proposals of Tortorella, Hayes e M. Bonifay). The fragments were analysed according to their stratigraphic position, which allowed us to infer their absolute chronology and integration in the different Roman occupation phases of the site.

The African cooking ware circuit in southern Portugal was proposed based on the data of the Lagos site, but also with others from distinct places in the Algarve, whereby we conclude that those in which these ceramics have been registered were on the coast or easily accessible by river.
Palabras Clave

Cerâmica romana; Monte Molião; cerâmica de cozinha africana; Algarve.

\section{KEY WORDS}

Roman pottery; Monte Molião; African cooking ware; Algarve.

1 Trabalho elaborado no contexto do Projecto "Monte Molião na Antiguidade".

a.m.arruda@letras.ulisboa.pt

alvaro.prr@gmail.com 


\section{INTRODUÇÃO}

Monte Molião fica situado numa colina de forma geral elipsoidal, de topo ligeiramente aplanado, com uma cota máxima de 30 metros, localizada na margem esquerda da Ribeira de Bensafrim (Fig. 1), integrando-se numa freguesia urbana da cidade de Lagos.

Os trabalhos arqueológicos levados a efeito no sítio entre 2006 e 2016 são já extensos, tendo sido escavada uma área total de $600 \mathrm{~m}^{2}$. Foram concretizados em diversos sectores: o A, localizado a Este, junto à Rua do Molião; o B no topo; o C, na vertente Sul (Fig. 2).

Esses trabalhos permitiram detectar uma ocupação pré-romana, datada, genericamente, entre os meados do século IV e o II a.n.e. (Arruda et al., 2014). A que corresponde à época romana divide-se em duas grandes fases, uma republicana (século II e I

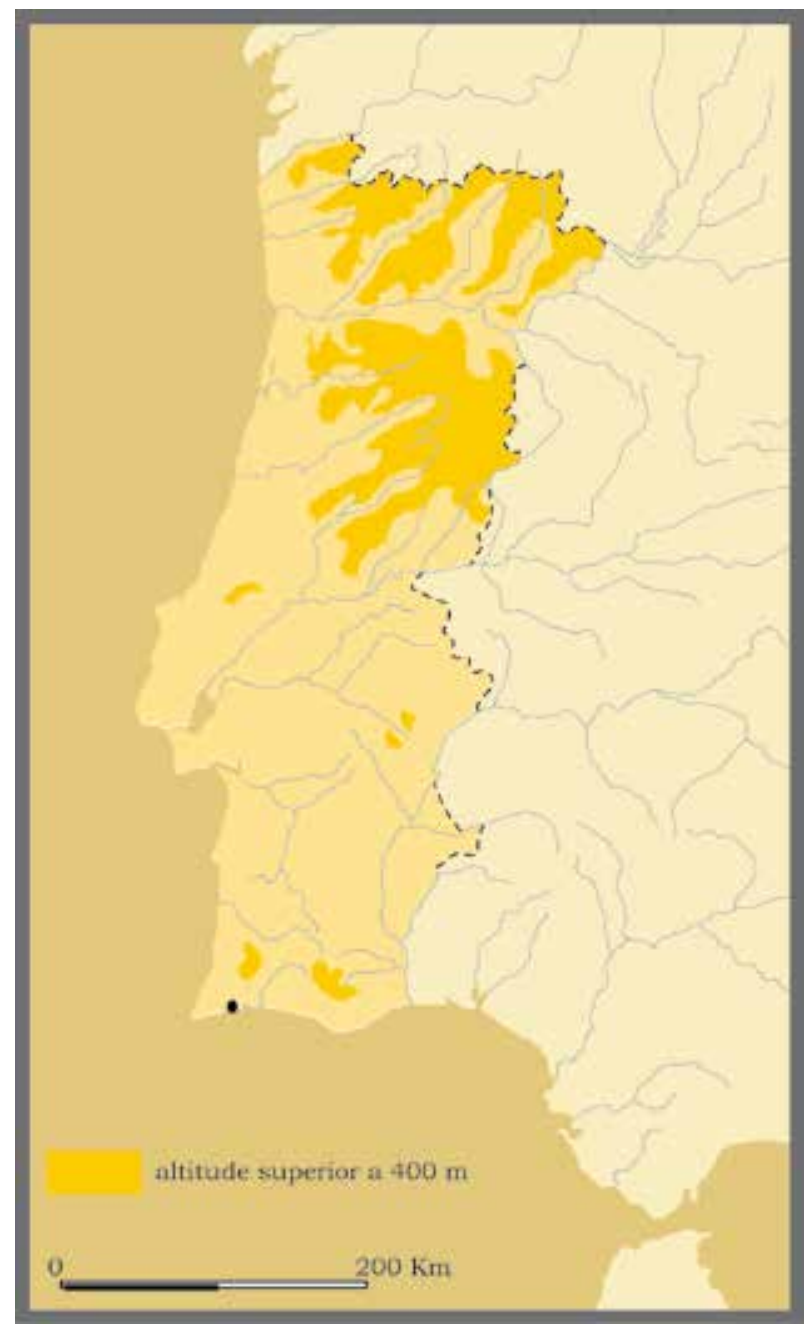

Fig. 1. Localização de Monte Molião, Lagos (Portugal).
a.n.e.)(Arruda e Sousa, 2010; Arruda e Pereira, 2010; Sousa e Arruda, 2014) e outra imperial (séculos I e II d.C.) (Entre outros Arruda et al., 2008; Arruda Viegas e Bargão, 2010; Viegas e Arruda, 2014). Foi nos níveis arqueológicos correspondentes a esta última fase que se recolheram os materiais que se estudam neste trabalho.

2. A cerâmica de Cozinha africana de Monte Molião

O conjunto de cerâmica de cozinha africana de Monte Molião totaliza 2005 fragmentos classificáveis, dos quais, contudo, só 1767 se encontravam em condições de ser tipificados, tendo sido estes que foram integralmente estudados de acordo com a sua forma, função, área de produção e contexto de consumo. Correspondem a 1611 bordos, 63 carenas, 88 fundos, 3 bojos e 2 asas, totalizando assim 1648 NMI.

Estes materiais foram recuperados em todos os sectores escavados, sendo mais abundantes no A, concretamente nas unidades estratigráficas correspondentes à fase de abandono do sítio, totalizando aqui $53 \%$ do total de fragmentos.

\subsection{As FORMAS}

Hayes 196

A forma de cerâmica de cozinha africana mais bem representada em Monte Molião é a 196 de Hayes, que corresponde a um prato que pode ter sido usado também como tampa (Fig. 3 e 4 ). Foram contabilizados $821 \mathrm{NMI}$ ( $50 \%$ do total do conjunto da cerâmica de cozinha africana). Infelizmente, nem todos os fragmentos foram passiveis de ser classificados de acordo com as duas variantes que Hayes definiu, uma vez que $401 \mathrm{NMI}$ correspondiam a bordos que podiam integrar-se, indistintamente, em ambas. Ainda assim, estamos seguros que 388 NMI pertencem à variante A (Fig. 3, 65-84; Fig. 4, 85-97), datada entre a segunda metade do século II e a época severa e 32 NMI à B (Fig. 4, 98107), característica do século II, de acordo com as datações de Ostia (Tortorella, 1981a e b).

501 dos 821 foram recuperados em contextos seguros, estando presentes nas UEs que correspondem ao momento final da ocupação do sítio (meados do terceiro quartel/finais do século II). Esta cronologia parece adaptar-se bem ao faseamento proposto para as diversas fases de produção destas cerâmicas (Bonifay, 2004, 225), muito especificamente para o que foi designado 


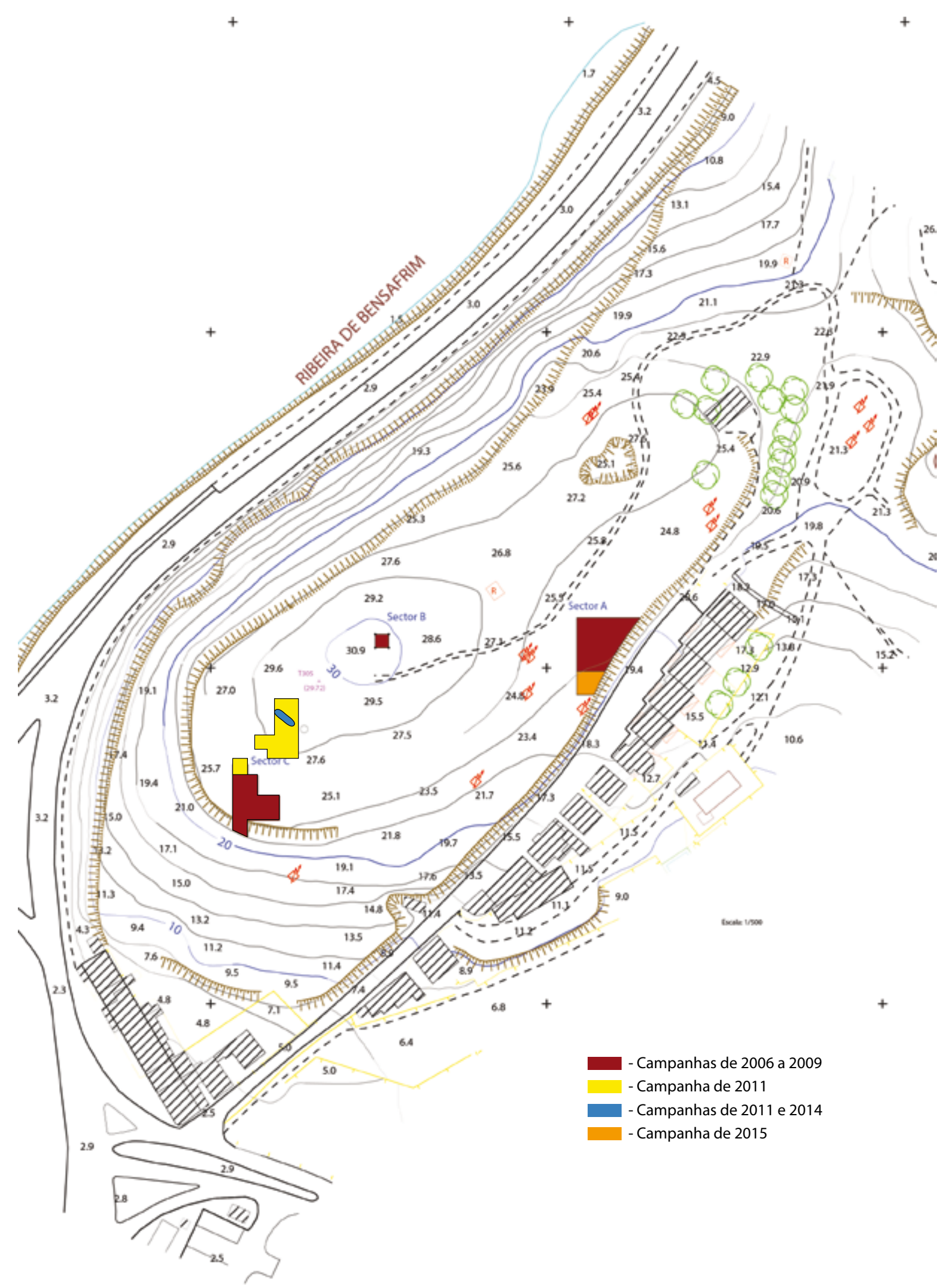

Fig. 2. As áreas escavadas em Monte Molião entre 2006-2016. 

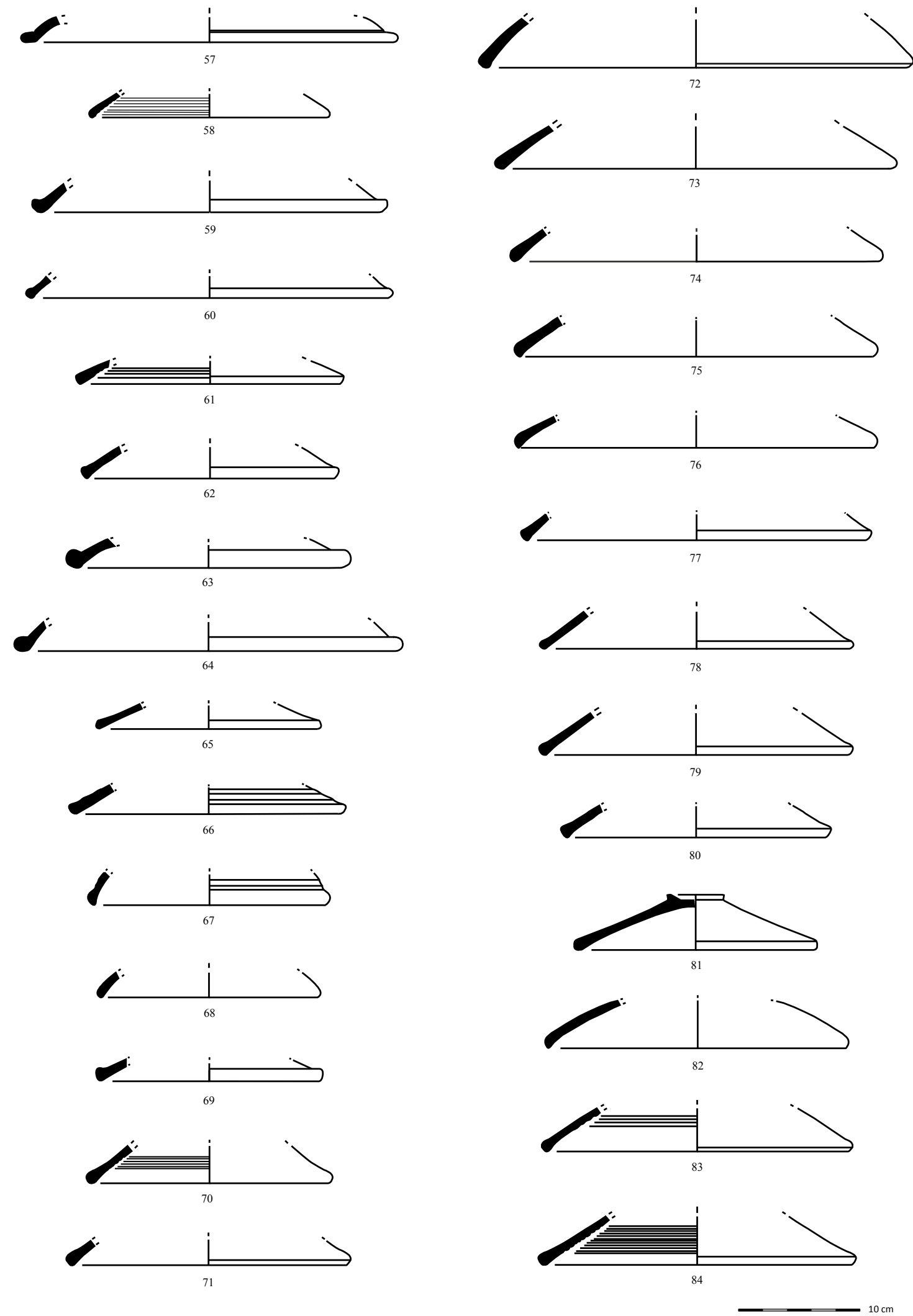

Fig. 3. 58-59: Hayes 185, variante A; 61-62: Hayes 185, variante C; 63-64: Hayes 195; 65-84: Hayes 196. 

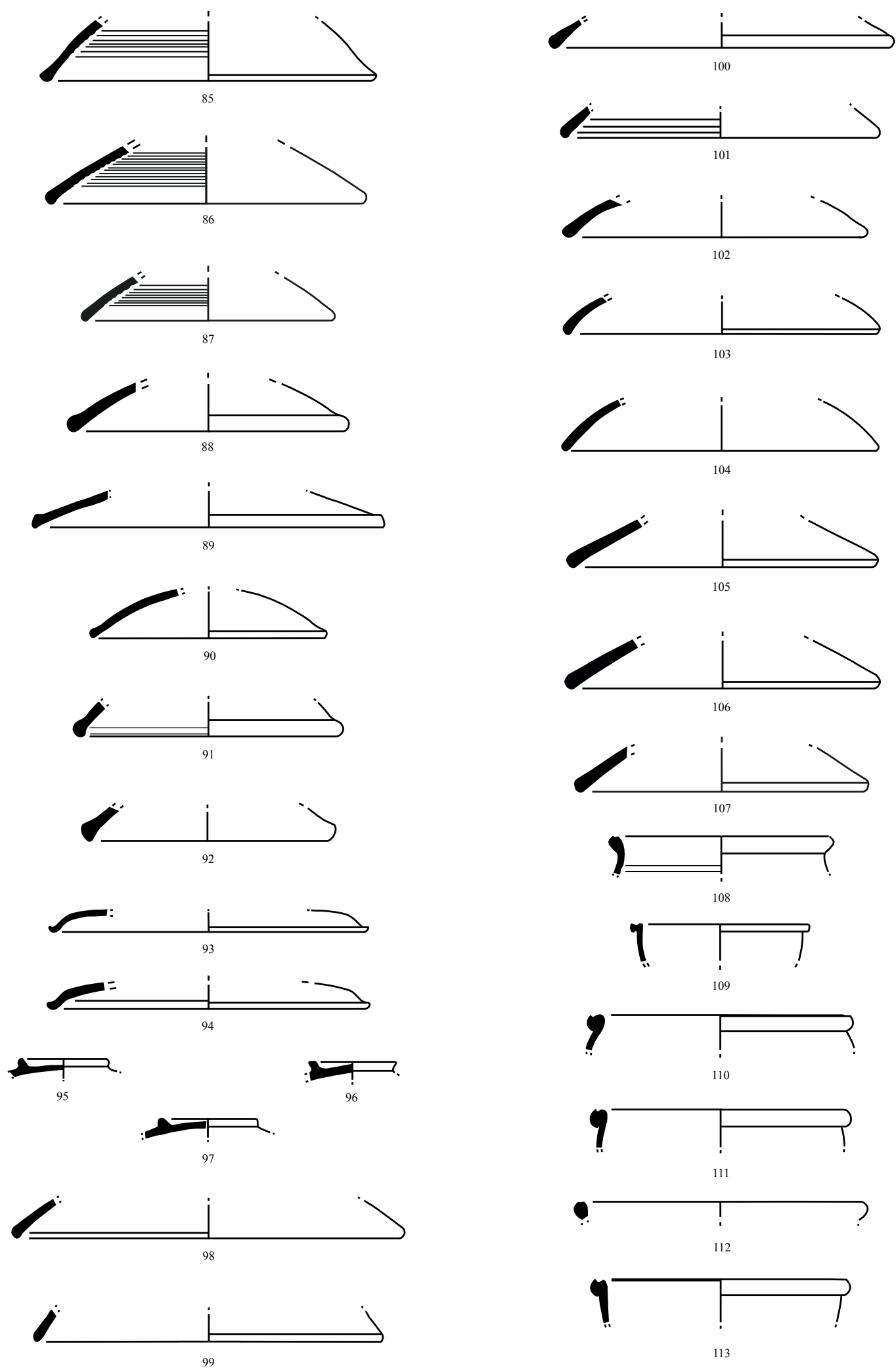

113

Fig. 4. Hayes 196 (85-97: variante A; 98-107: variante B); 108-112: forma Hayes 197. 
Forma clássica B, de bojo encurvado e fundo côncavo, característica do século II, de acordo com as datações de Ostia (Tortorella, 1981a).

O prato/tampa produzido no norte da Tunísia, com uma forma adaptável à caçoila Hayes 23 e ao tacho Hayes 197, está também muito bem documentado no restante território algarvio, como é por exemplo o caso de Ossonoba (Viegas, 2011), Balsa (Viegas, 2011), Quinta de Marim (Silva, Soares e Coelho-Soares, 1992), Cerro da Vila (Teichner, 2008) e Vidigal (Pereira, 2012). No restante território português da Lusitânia, registouse em Tróia (Magalhães, Brum e Pinto, 2014), Miróbriga-Chãos Salgados (Quaresma, 2012), Ilha do Pessegueiro (Silva e Soares, 1993) e São Cucufate (Pinto, 2003).

No litoral da Andaluzia, da região valenciana e da Catalunha a forma está também presente, em quantidades apreciáveis, por exemplo em Córdova (Carrillo Díaz-Pinés e Morillo Redondo, 1996), na vila romana de EIs Tolegassos (Viladamat, Gerona), em contextos fechados que foram datados da transição do século II para o III (Casas e Nolla, 1986-1989, 211-212), e em Roses, também em Gerona, no edifício A, com cronologia atribuída ao último quartel do século II (Nieto, 1993, 191). Em Guadix, este tipo foi registado em níveis do século II e em outros do III (Doblas Peguero, 2013, 34). Estas datações compaginam-se bem com a que foi verificada em Monte Molião. Em Valência, contudo, o mesmo prato/tampa foi datado do século I (Sánchez Martín, 2003, 39; Arnau Davó et al., 2003, 178).

\section{Hayes 197}

O tacho da forma 197 (com bordo destacado em relação à parede e ranhura na parte superior para encaixe da tampa) é também numeroso, tendo-se podido contabilizar 484 NMI (29\% do conjunto global), distribuídos pelos Sectores A, B e C: 472, 1 e 11 NMI, respectivamente (Fig. 4, 108-112; Fig 5; Fig. 6, 140-146).

Em termos contextuais, foram apurados 337 NMI, dos quais 316 NMI datam, maioritariamente, de meados do terceiro quartel/finais do século II, ou seja do momento final da ocupação.

Esta abundância não causa nenhuma estranheza, uma vez que esta é uma das formas de cerâmica de cozinha africana mais bem representada em todo o império romano, podendo ser encontrada em Itália, Austria, França, Espanha, Líbia, Argélia e Tunísia (entre outros: Hayes, 1972; Tortorella, 1981a; Bonifay, 2004).

No território peninsular, nas antigas províncias da Bética, Tarraconense e Lusitânia, esta forma teve uma grande difusão, podendo encontrar-se praticamente em todos os sítios de época imperial romana (Aguarod Otal, 1991, 281; Roca Roumens e Fernandez Garcia, 2005, 266). Destacam-se aqui, pela cronologia dos contextos de recolha, os exemplares de Córdova (Carrillo Díaz-Pinés e Morillo Redondo, 1996), os de Guadix (Doblas Peguero, 2013, 34) e os de Valência (Arnau Davó et $a l, 2003,178)$, estes últimos do século I.

Em Portugal, a forma está presente em todos os sítios para os quais há dados publicados, concretamente Balsa (Viegas, 2011), Ossonoba (Viegas, 2011) e Cerro da Vila (Teichner, 2008).

Trata-se de uma forma de cerâmica comum, que corresponde a um recipiente destinado à preparação e confecção de alimentos: o tacho. Exibe um bordo destacado em relaçãoà parede, com ranhura na parte superior para encaixe da tampa, que foi evoluindo progressivamente para o aprumar relativamente à parece. Apresenta caneluras na parede interna e fundo abaulado e tem estrias concêntricas no exterior. Proveniente do norte da Tunísia, tem uma cronologia compreendida entre a primeira metade do século II e o final do século IV e inícios do V (Tortorella, 1981a, 211).

\section{Hayes 23}

Menos abundante, mas podendo, ainda assim, englobar-se no grupo das formas maioritárias de cerâmica de cozinha africana de Monte Molião, esté a caçoila de bordo voltado para o interior, paredes abertas e fundo convexo e estriado, da forma 23 de Hayes, muito especialmente da sua variante B (Fig. 7, 2-27). Contabilizaram-se $207 \mathrm{NMI}$, mas apenas 137 NMI foram encontrados em contextos seguros.

Esta forma, nesta variante, é uma das mais abundantes no Mediterrâneo ocidental (região valenciana, Catalunha) e na costa atlântica (Bética). A sua presença é considerável no Vale do Guadalquivir (Roca Roumens e Fernandez García, 2005, 264) e na Lusitânia, concretamente em Ossonoba (Viegas, 2011), Balsa (Viegas, 2011) e Cerro da Vila (Teichner, 2008), no Algarve, e em Tróia (Magalhães, Brum e Pinto, 2014, 701-705). A maioria dos contextos do litoral espanhol onde este tipo foi identificado foram datados do século II. 

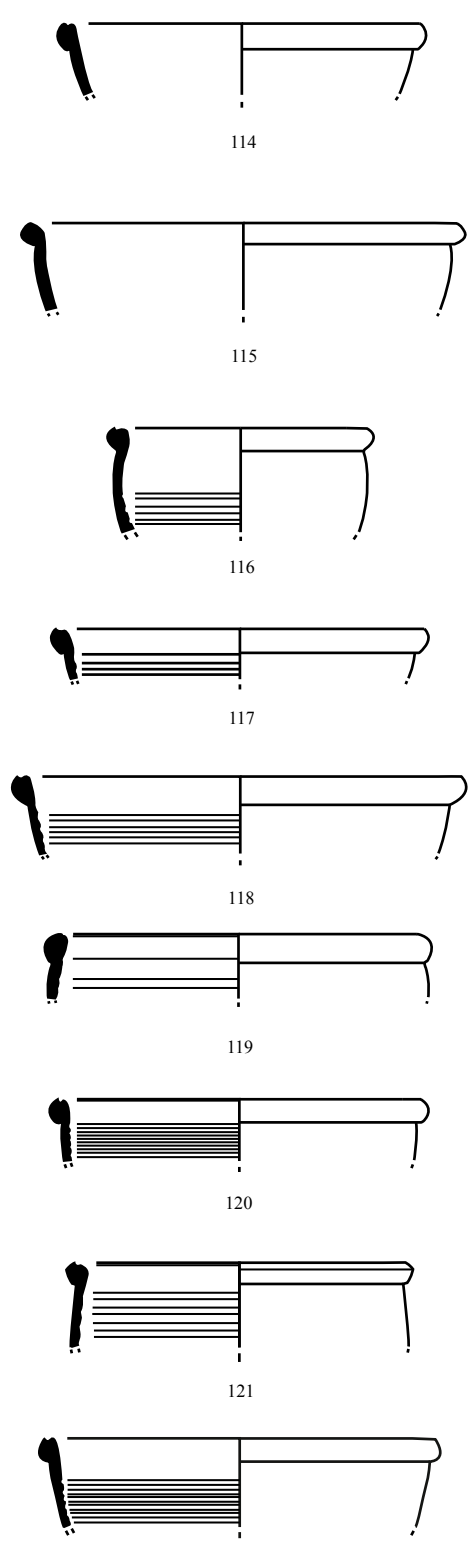

122
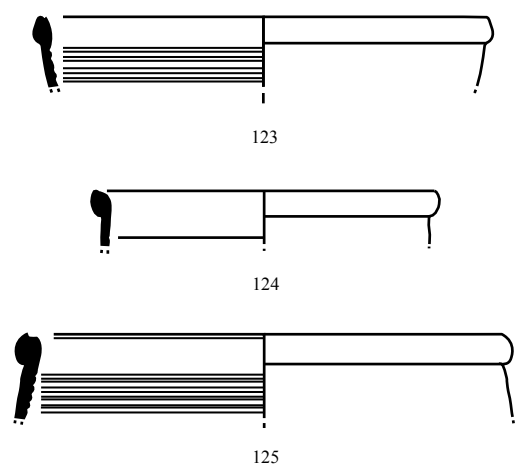
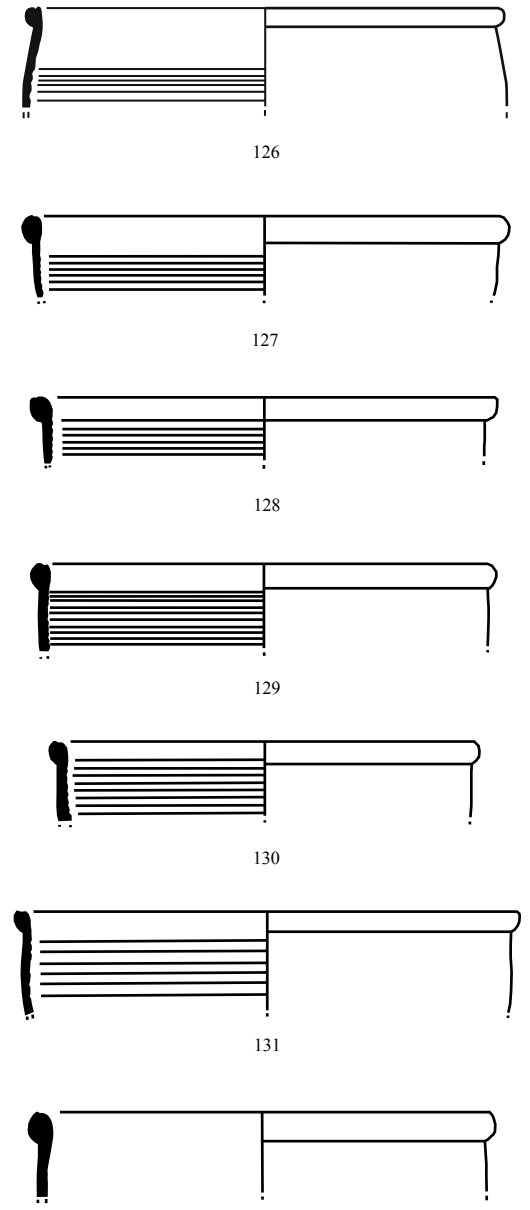

132

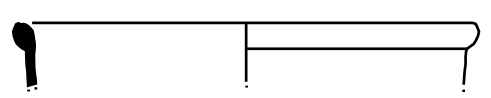

133
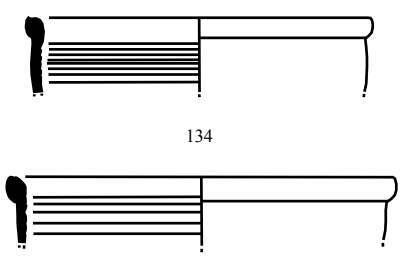

135
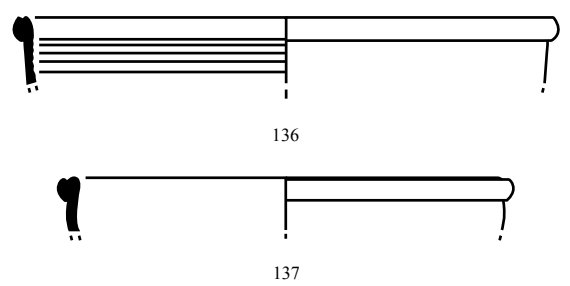

Fig. 5. Hayes 197. 


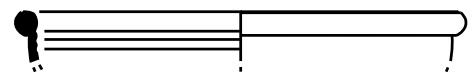

138

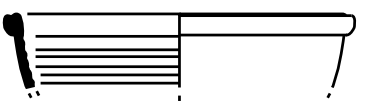

139

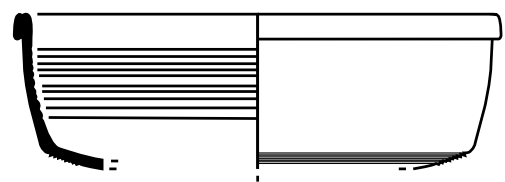

140

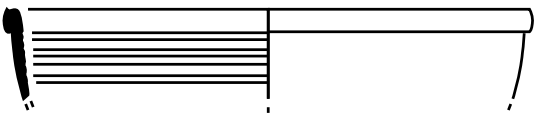

141

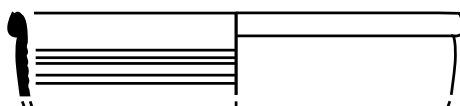

142

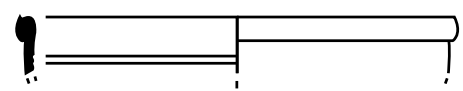

143

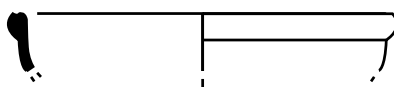

144

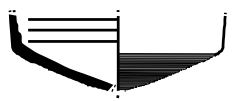

145
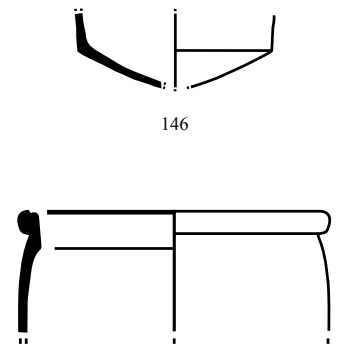

147

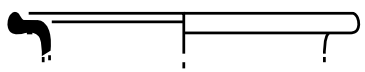

148

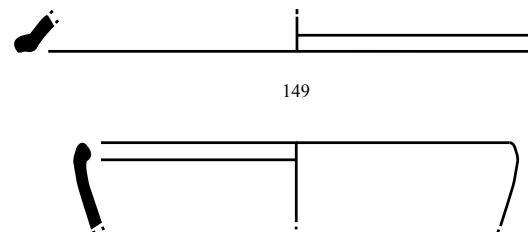

150

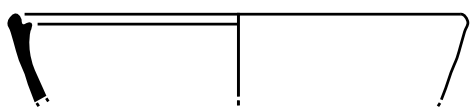

151

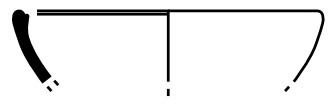

152

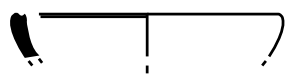

153

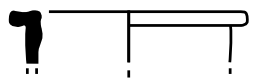

154

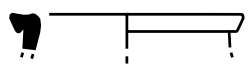

155

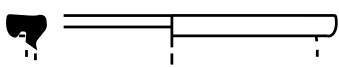

156

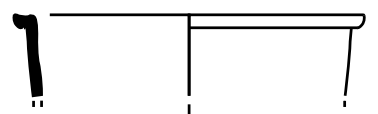

157

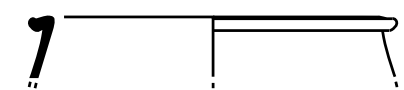

158

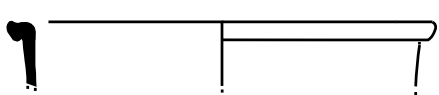

159
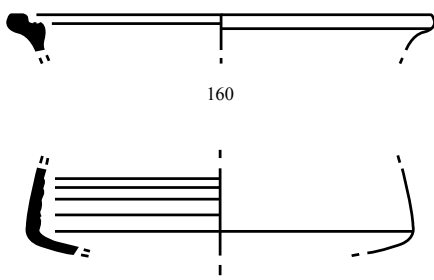

161

Fig. 6. 140-146: Hayes 197; 147-148: Hayes 199; 149: Ostia I 264; 150-153: Ostia II, 306; 154: Ostia II, 310, Hayes 198; 155-159: Ostia II, 312; 160: Ostia II, 314; 161: Jarro ou fervedor. 

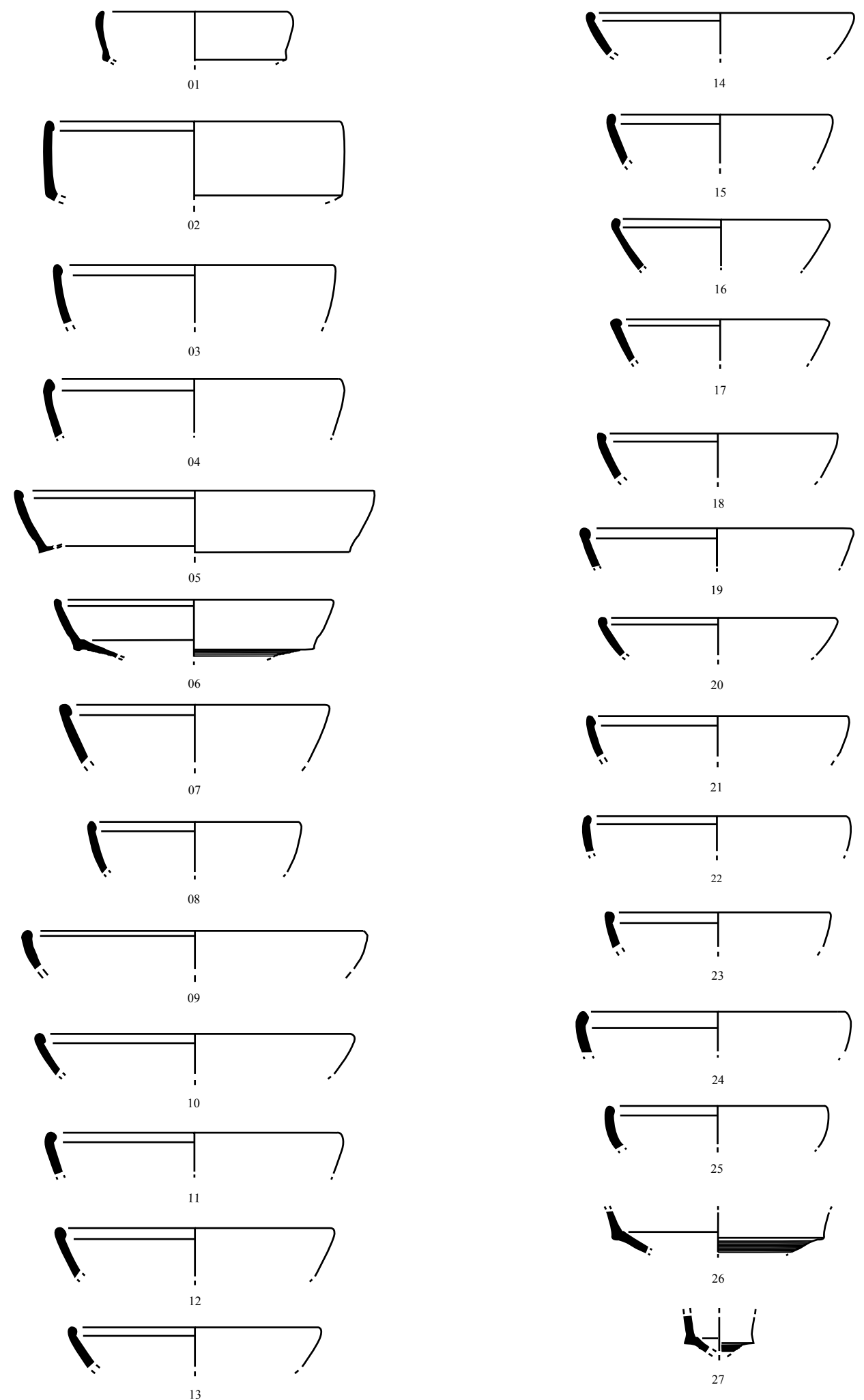

Fig. 7. 1: Hayes 23, variante A; 2-27: Hayes 23, variante B. 
A variante $\mathrm{A}$ é bastante inferior em número (Fig. 7, 1), com apenas três NMI registados, situação se compagina com a verificada na restante Península Ibérica, onde a a sua presença é diminuta, apesar de estar atestada em alguns sítios do vale do Guadalquivir e da província Tarraconense (Roca Roumens e Fernandez García, 2005, 265).

A forma 23 de Hayes foi produzida na área Tunes setentrional e na região de Cartago (Bonifay, 2004), parecendo a variante $B$ ligeiramente mais tardia do que a $\mathrm{A}$, esta última maioritariamente proveniente de contextos datáveis entre a primeira metade do século II e o princípio do século IV (Bonifay, 2004, 211).

\section{Hayes $181 \mathrm{C}$}

A caçoila de bordo não espessado e com extremidade arredondada, parede em arco de círculo quase perfeito, fundo plano e amplo, ressalto interior na junção com o bojo, que foi classificada por M. Bonifay como Culinária B tipo 5 , variante C, é uma variante das três formas principais, a Hayes 181, produzida em diversas oficinas de Bizacena, tendo sido datada do final do século II e do III (Bonifay, 2004, 214).

Apesar de ser habitualmente uma das formas mais comuns de cerâmica de cozinha africana, nos conjuntos peninsulares, sobretudo no território espanhol, em Monte Molião, foram encontrados apenas $21 \mathrm{NMI}$ (1\% do conjunto total) (Fig. 8, no $37-$ 44). A maioria dos indivíduos, equivalente a $67 \%$ (14 NMI), é proveniente de contextos de meados/ finais do terceiro quartel do século II.

Esta forma apareceu também em vários sítios de época romana do território actualmente português, concretamente no Vale da Arrancada (informação de Vera de Freitas a quem agradecemos), Vidigal (Pereira, 2012), Tróia (Magalhães, Brum e Pinto, 2014) e Miróbriga (Quaresma, 2009). Na Catalunha, este tipo de caçoila foi registado, por exemplo, em Els Antigons (Reus, Tarragona) e em Roses (Gerona), em contextos dos finais do século II (Járrega Dominguez, 2008). Em Córdova, as escavações do teatro evidenciaram a sua presença em contextos dos finais do século II/Inícios do III (Carrillo Diáz Pinés e Murillo Redondo, 1996, 1315), tal como na área extramuros da Colonia Patricia, no último quartel do século II (Vargas Cantos, 2000, 182), tal como na casa palácio de Orive (Carrillo Diáz Pinés e Murillo Redondo, 1996). Ainda na Província de Córdova, em Cercadilla, verificou-se a mesma si- tuação em termos cronológicos (Moreno Almenara et al., 2003). Ainda na Bética, refira-se o caso de Baelo Claudia, por exemplo, com escassos exemplares datados do século II (Bernal et al., 2007). Estas cronologias estão de acordo com o que foi observado em Monte Molião.

\section{Hayes 182}

O prato/tampa da forma Hayes 182 foi classificada por M. Bonifay (2004) no grupo Culinária B, tipo 6, estando datado desde os meados do século II até ao século III.

Em Monte Molião, foram encontrados $71 \mathrm{NMI}$ (4\% do conjunto total) (Fig. 8, no 45-56), com a seguinte distribuição tipológica: variante $\mathrm{A}$ - quatro (Fig. 45-46), variante B - 30 (Fig. 8. № 47-52), variante $\mathrm{C}-37$ (Fig. $8, \mathrm{n}^{\mathrm{0}} 53-57$ ).

Ainda que a forma seja minoritária no conjunto, uma vez que representa apenas $4 \%$ da Cerâmica Africana de Cozinha, os 71 indivíduos recolhidos não têm paralelo nos restantes sítios portugueses em termos numéricos. De facto, a sua escassez é real, estando ausente da grande maioria dos locais para os quais há dados publicados, registando-se a sua presença apenas em Vale da Arrancada (informação pessoal de Vera de Freitas), Tróia (Magalhães, Brum e Pinto, 2014) e São Cucufate (Pinto, 2003). A mesma escassez verifica-se no caso espanhol, onde a forma, apesar de existir em alguns sítios do Sul, é sempre rara.

Tal como sucede nos restantes casos, $52 \%$ dos fragmentos desta forma foram recolhidos em Unidades Estratigráfica dos meados do terceiro quartel do século II (fase do momento final da ocupação).

\section{Hayes 184}

A forma Hayes 184 (Culinária B tipo 7 de M. Bonifay, 2004, 217), a caçoila do tipo tajine (Salomonson, 1970, 64) de tamanho pequeno, possivelmente destinada ao uso individual, é rara em Monte Molião (Fig. 8, $\mathrm{n}^{\mathrm{0}}$ 28-32), onde foram encontrados nove NMI (1\% do conjunto total), apenas das variantes A (Fig. 8, n⿳0 28-29) e B (Fig. $8, n^{0} 30-32$ ), em níveis datados da última fase de ocupação (meados do terceiro quartel do século II). Refira-se que esta cronologia é compatível com a que se atribui, justamente, às variantes $\mathrm{A}$ e $\mathrm{B}$ desta forma, respectivamente século II e final do II e III, estando ausente, no sítio, a C, mais tardia, da segunda metade do III e do IV (Bonifay, 2004, 217). 

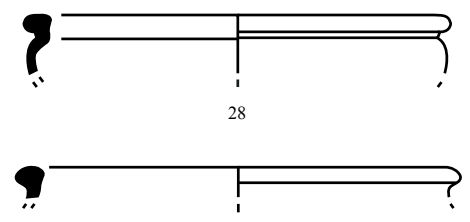

29
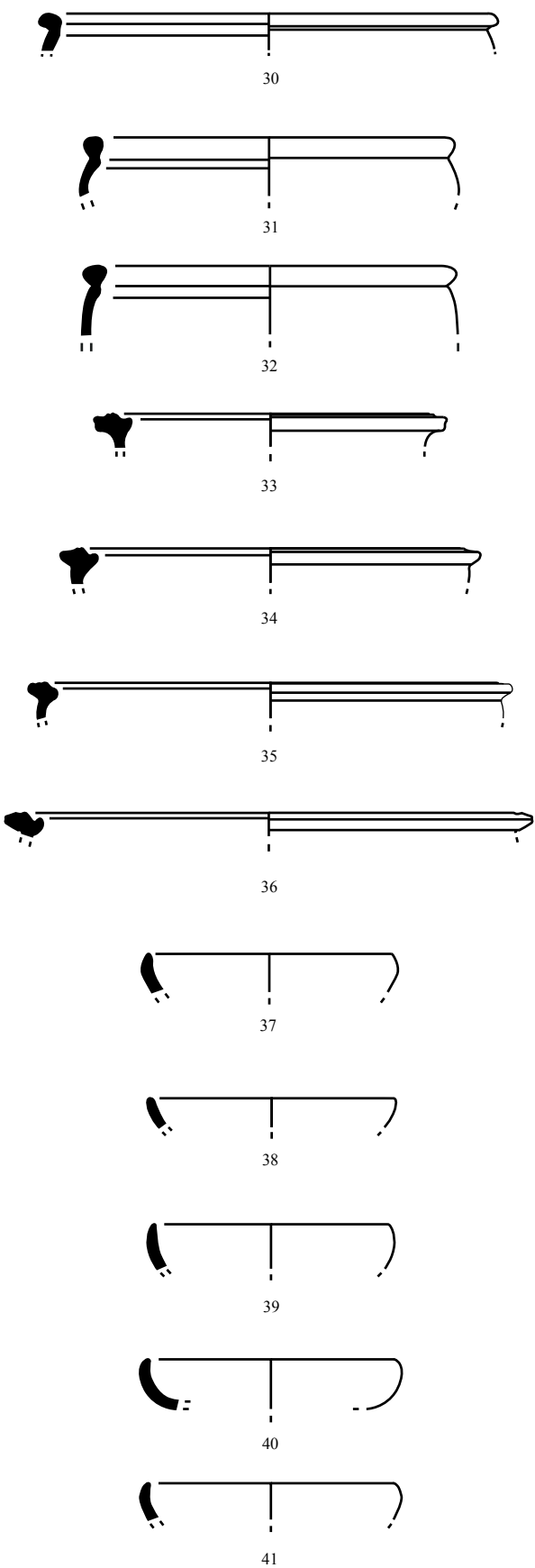
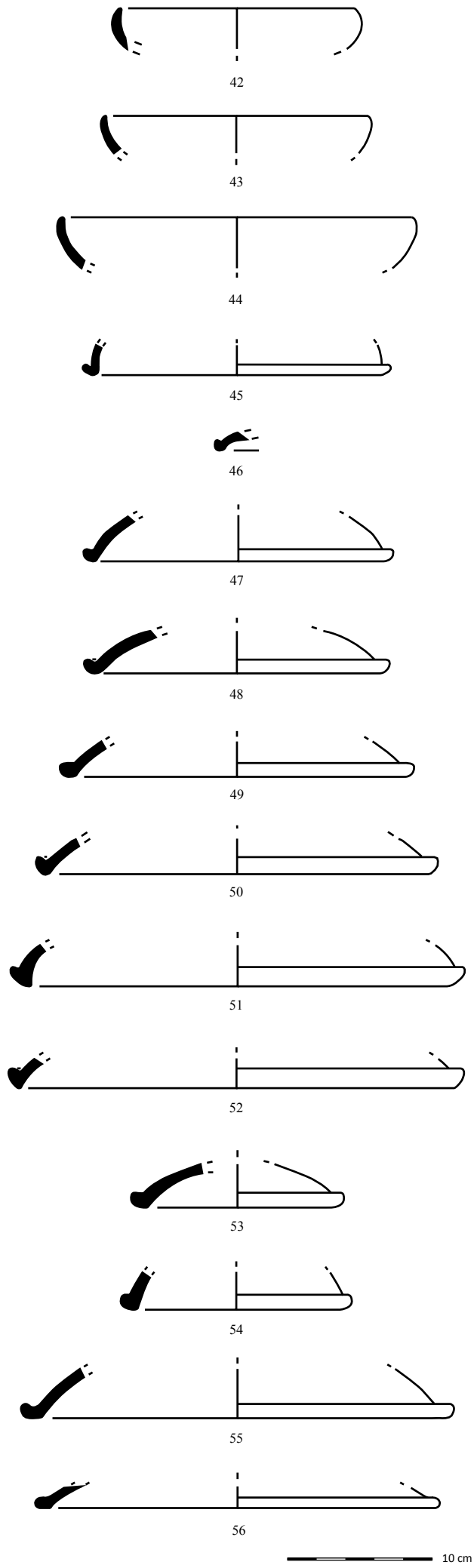

Fig. 8. 28-29: Hayes 184, variante A; 30- 32: Hayes 184, variante B; 33- 36: Sidi Jdidi 3; 37-44: Hayes 181 C; 45-46: Hayes 182, variante A; 47-52: Hayes 182, variante B; 53-57: Hayes 182, variante C. 
Este tipo de caçoila, aparentemente pouco exportado, está ausente de todos os outros sítios do território português.

\section{Hayes 185}

Corresponde ao prato/tampa da caçoila Hayes 184, tendo sido classificada como Culinária B tipo 9, por M. Bonifay (Bonifay, 2004, 221).

Em Monte Molião, foram encontrados oito NMI (1\% do conjunto total) (Fig. 3, no $58-62$ ), dois quais dois são da variante A (Fig. 3 58-59), datada do fim do século I/inícios do II, e seis da C (fim do século II e meados do século III) (Fig. 3, no 61-62). Em termos de registo contextual, 67\% (6 NMI) foram recolhidos em contextos datados dos meados do terceiro quartel do século II (fase do momento final da ocupação).

Os oito indivíduos desta forma representam um valor consideravelmente baixo, mas são ainda assim, face ao restante território nacional, um número considerável, uma vez que apenas em Tróia (Magalhães, Brum e Pinto, 2014) se registaram fragmentos desta morfologia. A sua raridade no sul peninsular em geral, é também de realçar neste contexto.

\section{Hayes 195}

Em Monte Molião, foram apenas encontrados dois exemplares deste prato/tampa a similar à forma Hayes 182, com o bordo diferenciado, enrolado sobre si mesmo, e com a canelura a meio do bojo (Fig. 3, $\mathrm{n}^{\mathrm{o}}$ 63-64). Um dos contextos de recolha está datado de meados do terceiro quartel do século II (momento final da ocupação), enquanto o outro é superficial.

Existem poucas referências desta forma no norte da Tunísia. No entanto, os poucos exemplares encontrados em Cartago pertencem, cronologicamente, aos séculos II e III (Bonifay, 2004, 227).

Tal como foi registado para a forma anterior $(\mathrm{H}$. 185), apenas Tróia (Magalhães, Brum e Pinto, 2014) ofereceu fragmentos do prato / tampa Hayes 195.

\section{Hayes 199}

Dos tachos abertos, com paredes altas e verticais, fundo arredondado, exterior do bordo e das paredes enegrecido, com socalco para encaixe de tampa, englobados na forma Hayes 199 (sucessora da 198 e contemporânea da 197 - Hayes 1972, 210 e Tortorella, 1981a, 218-219, tav. CVII, fig.4), apenas se conhecem dois exemplares em Monte Molião
(Fig. 6, no 147-148), um dos quais com lábio espessado junto à parede, realçando um ligeiro perfil abaixo do bordo.

Tradicionalmente, datava-se entre o final dos séculos II e século III, mas a cronologia foi fixada entre os finais dos Julio-Claudios e os inícios dos Flávios, de acordo com os dados recuperados na Tarraconense (Aguarod Otal, 1991, 275-276).

A forma é inédita no território actualmente português.

\section{Sidi Jdidi 3}

A forma Sidi Jdidi 3 (Culinária C tipo 25 de Bonifay) corresponde a uma caçoila de bordo espesso, encurvado para o exterior, marcado por duas estrias no topo, o que lhe dá um aspecto claramente "trífido"; as paredes são verticais e o fundo é convexo. A sua cronologia estende-se desde a primeira metade do século II até à primeira metade do século III (Bonifay, 2004, 234).

De acordo com a evolução proposta pelo investigador francês, os nossos exemplares (Fig. $\left.8, \mathrm{n}^{\mathrm{o}} 33-36\right)$ poderiam caber nas variantes tardias, de meados do século III, de lábio compacto. Mas a sequência de Molião (Viegas e Arruda, 2014) contraria essa datação, uma vez que os exemplares algarvios foram recuperados em contextos datados da segunda metade do século II.

Tendo sido produzida no golfo de Hammamet, este tipo de caçoila está bem difundido no norte de África, documentando-se também Ostia na primeira metade do século III (Bonifay, 2004).

No Monte Molião, foram encontrados cinco NMI, em contextos datáveis de meados/terceiro quartel do século II.

\section{Ostia I 264}

O prato com bordo dobrado para o exterior Ostia I 264 está, no Monte Molião, representado por apenas dois NMI (Fig. 6, no 149), encontrados nas UEs 1 e 1140, dos Sectores A e C, respectivamente. A UE 1 é de superfície, mas a 1140 do Sector C corresponde a um contexto datado dos meados do terceiro quartel do século II, ou seja, no momento final da ocupação do sítio. Esta cronologia não é incompatível com o que é conhecido para a forma em geral, datada a partir da época severa (século II).

Este tipo de prato/tampa está muito bem documentado no Mediterrâneo ocidental (Tortorella, 1981a, 214), principalmente na zona costeira, com algumas incursões para o interior, 
concretizadas, muito possivelmente, por via fluvial, como são os casos dos vales do Guadalquivir e do Ebro (Sánchez Martín, 1995, 269). Para o território espanhol, os casos que fornecem cronologias são o de Málaga (Serrano Ramos, 2000, 31) e o do Córdova (Monterroso Checa, 2002, 218).

\section{Ostia II 306}

A caçoila destinada a cozinhar a vapor designada por Ostia II, 306 de bordo bífido, paredes suavemente convexas e fundo também convexo, está representada em Monte Molião por quatro NMI (Fig. 6, no 150-153). Em termos de cronológicos, um deles encontrou-se me contexto datado entre os finais do século I e a primeira metade do século II, três outros em estratos dos meados/terceiro quartel do século II, sendo o último de superfície.

A forma encontra-se difundida por todo o Mediterrâneo ocidental (Tortorella, 1981a, 216), concretamente na costa catalã e no vale do Ebro (Sánchez Martín, 1995, 269). A cronologia estendese desde a época de Tibério até à primeira metade do século III (Tortorella, 1981a, 216). Uma datação próxima à observada em dois dos casos de Monte Molião é a obtida em Roses, Gerona (Nieto, 1993, 181), do último quartel do século II. A sua presença em Valência, em níveis tardo-augustanos, permitiu recuar a produção e exportação desta forma para momentos consideravelmente antigos (Albiach et al., 1998), apesar de se saber que na mesma colónia o mesmo tipo de caçoila também foi usado na época tiberiana (Alvarez et al., 2003)

\section{Ostia II, 310; Hayes 198}

Um único exemplar deste tipo de caçoila foi encontrado em Monte Molião (Fig. 6, nº 154).

A forma parece inspirar-se em modelos itálicos antigos, e as produções africanas documentam-se a partir de finais do século I a.C., tal como ficou comprovado em Tarragona (Ruiz Arbulo et. al., 2010, 230). No entanto, a sua presença em contextos do final do século I e primeira metade do II é frequente (Tortorella, 1981a, 218-219), também na Península Ibérica (Gómez Bravo e Miñano Dominguez, 1999, 319).

No Monte Molião, a peça é proveniente do Sector A (UE 85), correspondente ao abandono do sítio, no final do século II.
Ostia II, 312

O tacho de grande capacidade, com bordo horizontal, desenvolvido para o exterior, com paredes verticais, e uma patine cinzenta na parede externa, é habitualmente datado desde a época dos Flávios até aos meados do século II. (Tortorella, 1981a, 218).

Em Monte Molião, está presente com cinco NMI (Fig. 6, n⿳0 155-159), dois dos quais cronologicamente enquadráveis nos finais do século I / primeira metade do século II e os dois restantes nos meados / terceiro quartel do século II (UE 85 e 1147).

A sua presença não é comum no território peninsular, mas conhece-se por exemplo em La Azohía, Cartagena, em estratos que foram datados entre os finais do século I e os meados do II (Goméz Bravo e Miñano Domínguez, 1999, 319) ou na área de Córdova, em finais do século II (Moreno Almenara et al., 2003).

\section{Ostia II, 314}

As panelas deste tipo (com bordo horizontal, desenvolvido para o exterior e com encaixe para a tampa) surgem, segundo Tortorella (1981a, 218), na época Flávia e Trajana (séc. I-II), havendo registo da sua presença também em momento tardo flávio, na Tunísia central (Tortorella, 1981a). Contudo, os trabalhos em Valência permitem equacionar a hipótese de uma exportação para a Península Ibérica já nos finais do reinado de Augusto (Ribera i Lacomba, 2010), situação que foi também reconhecida em Tarragona (Aquillé, 1995)

No Monte Molião, foi encontrado um único fragmento (Fig. 6, $\mathrm{n}^{\mathrm{o}}$ 160) passível de ser assim classificado (um NMI), em nível correspondente ao momento de abandono do sítio.

Jarro ou fervedor

Um fragmento de parede que pode classificarse como jarro foi recolhido em Monte Molião (Fig. $6, n^{0} 161$ ). Trata-se de uma forma fechada, para conter, aquecer e servir líquidos.

Estes jarros apresentam um bojo baixo, fundo convexo e gargalo longo e troncónico com boca trilobada, munido de uma asa nervurada. São objectos muito frágeis, aparecendo frequentemente muito fragmentados e em pequenas quantidades nos contextos dos séculos II ao IV em Pupput e Nabeul (Bonifay, 2004).

Contudo, a forma é bem conhecida e parece ter tido origem na Gália como reprodução dos jarros 
metálicos, iniciando-se o seu fabrico na Europa ainda no período de Augusto-Tibério. A difusão foi ampla na segunda metade do séc. I d.C., sendo conhecido em outros lugares na época romana, com grande desenvolvimento em África, onde foi produzida, a partir do século II (Bonifay, 2004, 229), na região da Bizacena.

Alguns autores defendem a possibilidade desta forma ter também a utilização de fervedouro (hipótese ainda não confirmada), uma vez que foram observados depósitos de calcário na sua superfície interna (facto verificado no exemplar encontrado em Monte Molião) e também pelo tipo de argila utilizada na sua confecção, muito resistente a altas temperaturas (Batigne e Desbat, 1996, 381-394). Esta característica permitiria ainda a utilização destes recipientes no transporte e serviço de líquidos quentes.

A “carena” de Monte Molião (Fig. 6, nº 161), com calcário no interior (o que mostra que o vaso a que pertenceu foi utilizado, com muita frequência, na fervura de água, foi encontrada no Sector A, em UE correspondente ao momento final de ocupação do sítio.

2.2. A CERÂMica de COZINHA AFricana de Monte MOLIÃO FORMAS E CRONOLOGIA: UMA LEITURA INTEGRADA DOS DADOS ESTRATIGRÁFICOS E CONTEXTUAIS

O conjunto de cerâmica de cozinha africana de Monte Molião merece ainda um comentário final no que se refere às formas identificadas e à sua representação no sítio.

Em primeiro lugar, não podemos deixar de referir que o conjunto é numeroso, constituindo o maior do actual território português. Tal facto, deve-se, seguramente, a factores que se relacionam sobretudo com a ausência de estudos sobre esta categoria cerâmica, pelo menos no que diz respeito ao Algarve. Com efeito, a investigação concretizada para os restantes sítios algarvios, como é por exemplo o caso de Baesuri, Balsa e Ossonoba (Viegas 2011) privilegiou, quase sempre, as cerâmicas finas e as ânforas, tendo a comum, incluindo, naturalmente, a de Cozinha Africana, sido quase completamente ignorada. No entanto, a sua importância no território algarvio é certamente grande, uma vez que esta incorpora, de forma significativa, os conjuntos cerâmicos de outros sítios algarvios estudados globalmente, como é por exemplo o caso de Cerro da Vila (Teichner, 2008) e do Vidigal (Pereira, 2012).
Relativamente ao restante território, a escassez de importações de cerâmica comum com origem no norte de África é um facto incontornável, podendo ser interpretada de forma diversa.

Queremos também deixar claro, desde já, que a Cerâmica de Cozinha Africana está presente a partir de uma fase relativamente precoce no sítio de Lagos, havendo dados estratigráficos seguros que comprovam a sua importação ainda no século I, mesmo que na sua segunda metade, concretamente em época flávia. Apesar disto, é claro, através dos mesmos dados, que o auge destas importações ocorreu nos momentos finais de ocupação do sítio, concretamente nas últimas décadas do século II, como aliás parece ter acontecido também no Cerro da Vila (Teichner, 2008). Esta realidade não destoa de outras conhecidas no actual território espanhol, na Andaluzia, na região valenciana e na Catalunha. Recorde-se que em Valência as primeiras importações desta categoria cerâmica datam ainda final do reinado de Augusto (Ribera i Lacomba, 2010) e em Tarragona podem ter-se iniciado nos finais do século I a.C. (Ruiz Arbulo et al., 2010), desenvolvendo-se, contudo, substancialmente na época flávia. Todavia, a segunda metade do século II corresponde ao auge das importações de cerâmica de cozinha africana, importações que parecem diminuir no século III, pelo menos de acordo com os dados de Guadix (Doblas Peguero, 2013) e de outros sítios andaluzes.

As formas documentadas em Monte Molião são também as mais comuns nestas produções (Fig. 9). Com efeito, a caçoila Hayes 23, o tacho Hayes 197 e o prato/tampa 196, que surgem quase sempre associados na maioria dos sítios que usaram esta categoria cerâmica, são sempre dominantes no conteúdo dos inventários. A associação das três formas relaciona-se com o a sua utilização conjunta, evidência que se torna clara em Molião, com o prato/tampa a corresponder a mais do dobro do que a soma das caçoilas e dos tachos (Fig. 10).

A presença de algumas formas raras deve explicar-se não só pelo facto do conjunto ser muito numeroso, mas eventualmente também pela sua cronologia "antiga" (Fig. 11).

Queremos também destacar o facto de as importações e o respectivo consumo destas produções de cerâmica comum, de uso culinário e com origem no norte de África, serem datáveis entre a segunda metade/finais do século I e a segunda metade/finais do século II. Com efeito, 


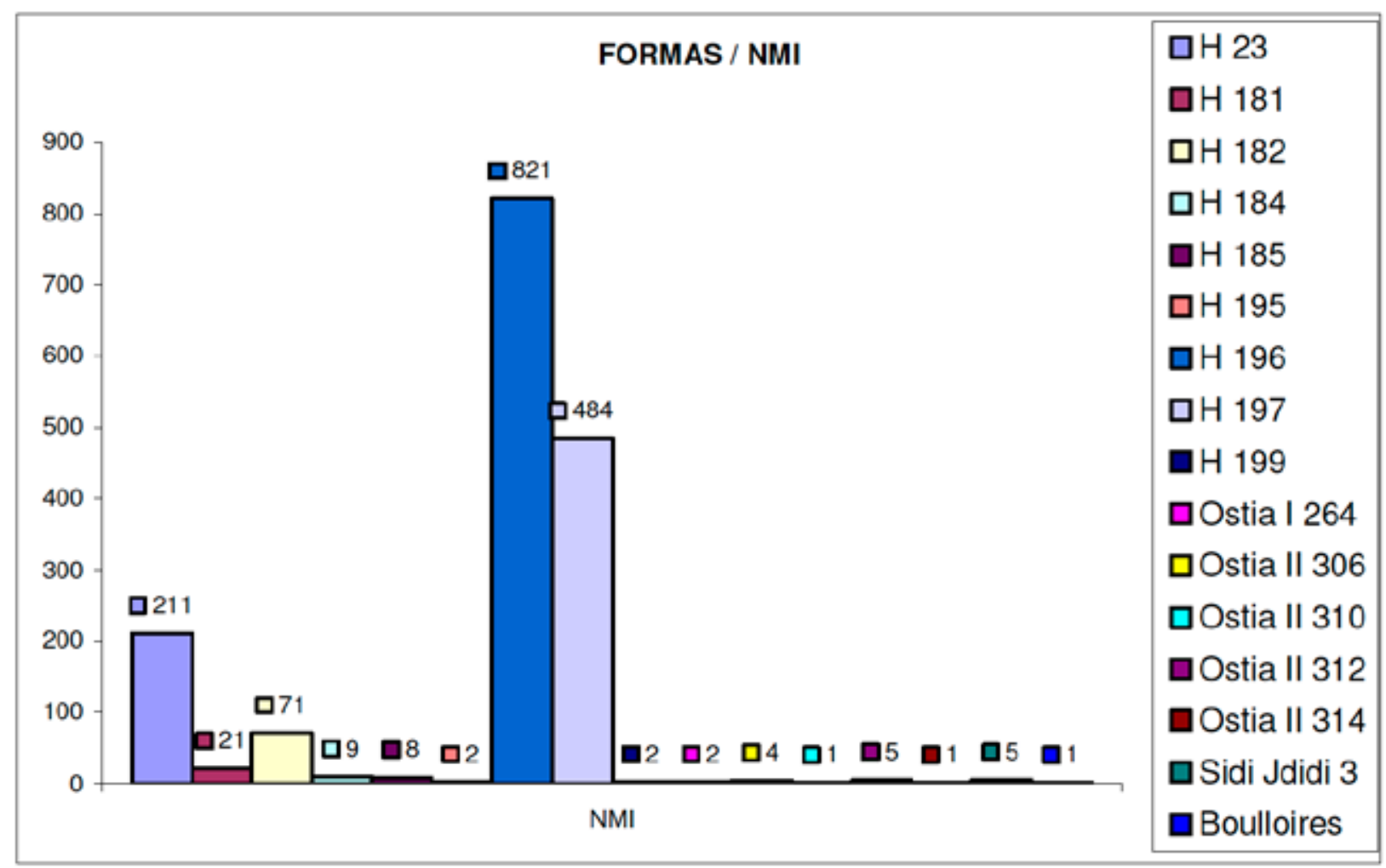

Fig. 9. A distribuição por formas da cerâmica de cozinha africana de Monte Molião.

\section{FORMAS DOMINANTES}

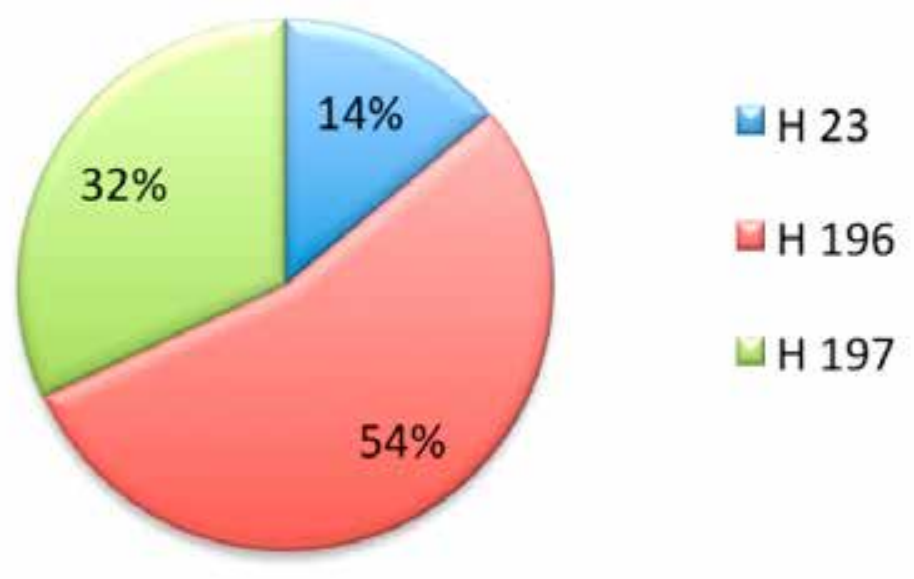

Fig. 10. As formas dominantes de cerâmica de cozinha africana de Monte Molião e a sua relação percentual. 


\section{FORMAS MINORITÁRIAS}

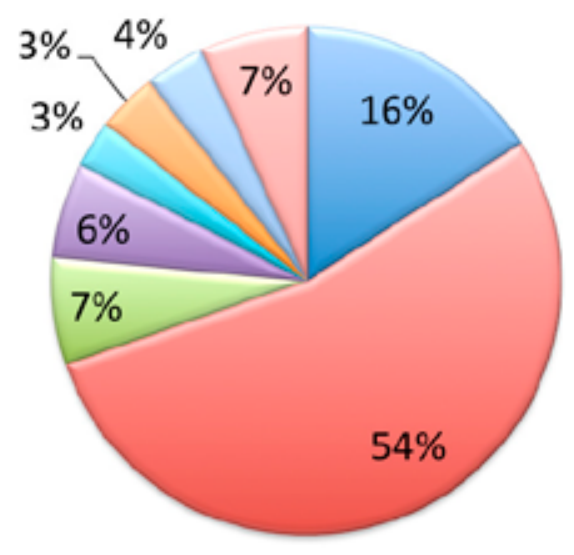

$\square \mathrm{H} 181$

$\square \mathrm{H} 182$

$\square \mathrm{H} 184$

$\square \mathrm{H} 185$

Ostia II 306

Ostia II 312

$\square$ Sidi Jdidi 3

$\square$ Outros

Fig. 11. A distribuição percentual das formas minoritárias de cerâmica de cozinha africana de Monte Molião.

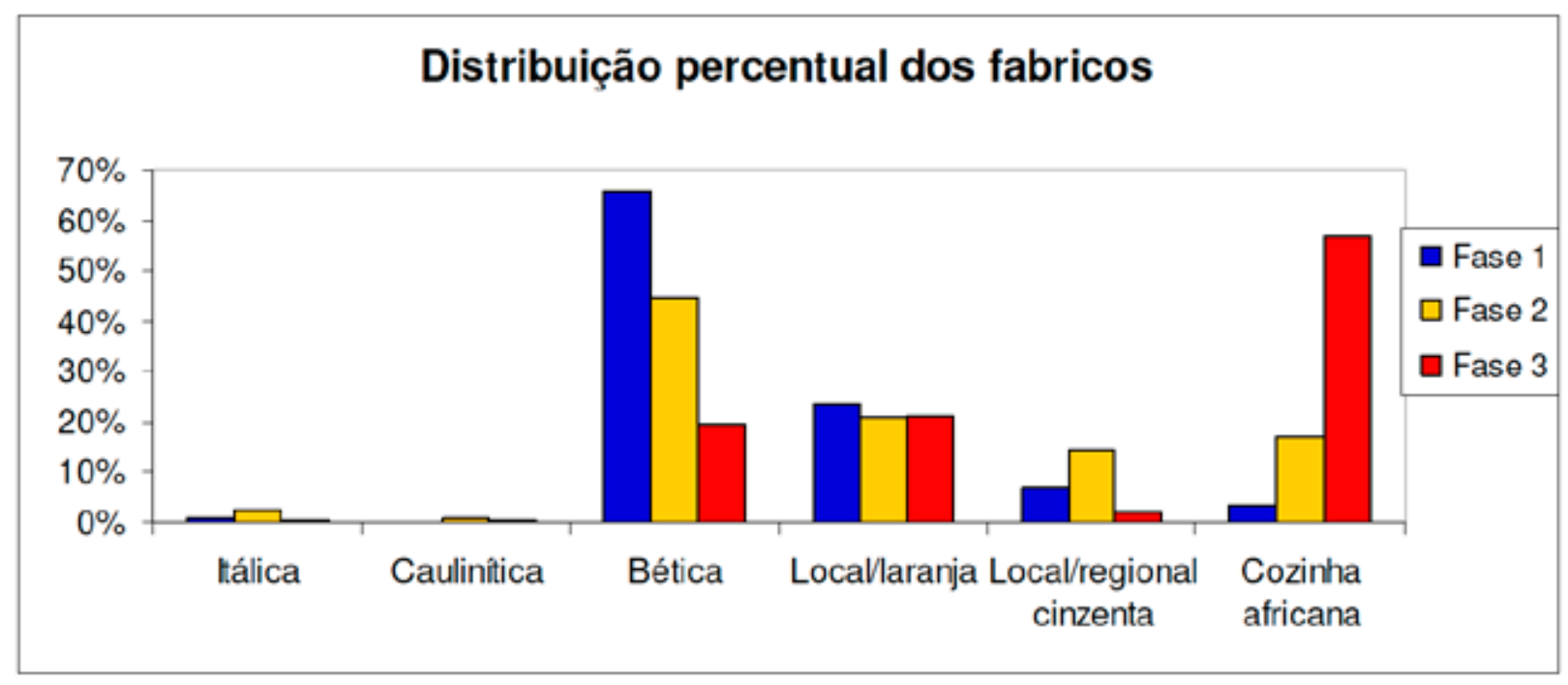

Fig. 12. A cerâmica comum de Monte Molião ao longo da sequência ocupacional romana, de acordo com a sua origem. 
os fragmentos que poderiam fazer recuar a cronologia das importações para momentos da dinastia julio-claudia são muito escassos, sendo largamente maioritários os recolhidos em contextos que se relacionam com aos últimos momentos de ocupação do sítio e com o seu abandono. Recordese, por outro lado, que estes momentos foram já datados do final do século II (Arruda 2007; Arruda et al., 2008; Arruda, Viegas e Bargão, 2010; Viegas e Arruda, 2014), o que permite também aferir datações para a circulação destes materiais norte africanos (Fig. 12).

Os restantes contextos onde se recolheu cerâmica de cozinha africana foram também já analisados em outros trabalhos (Arruda 2007; Arruda et al., 2008; Arruda, Viegas e Bargão, 2010; Viegas e Arruda, 2014), permitindo balizar mais seguramente as cronologias da própria Cerâmica de Cozinha Africana associada aos restantes materiais. Faz por isso sentido recordar aqui que no Sector A foram definidas três fases do momento Alto Imperial: fase 1 (época Flávia), fase 2 (finais do século I e primeira metade do século II) fase 3 (meados/finais do século II) (Viegas e Arruda, 2014, 255-257).

Nos compartimentos 2 e 7 , foram identificadas as UEs 61, 65, 90 e 151 imediatamente sobrepostas aos estratos de abandono do período Republicano (Viegas e Arruda, 2014, 255). Os espólios aqui recolhidos de cerâmica comum (no total de 120 NMI) estavam associados a produções de terra sigillata do Sul da Gália, datadas de 69 d.C. a 96 d.C.. Do grupo de Cerâmica Comum, 66\% correspondia a produções de pasta calcária, da Bética, 23\% ao âmbito local, de pastas alaranjadas, e 7\% referiase às de âmbito local/regional, de pastas cinzentas. As importações de cerâmica de cozinha africana integradas nesta primeira fase eram apenas de 3\% e estavam representadas pelas formas Prato/Tampa Hayes 196, a Caçoila Hayes 23 B e o Tacho Hayes 197.

As UEs 108, 112, 117 e 121, correspondentes à segunda fase, referem-se ao abandono dos compartimentos 5 e 6 . Documentam um período de difícil precisão cronológica, situando-se entre os finais do século I e a primeira metade do século II (Viegas e Arruda, 2014, 255). Foram encontradas 243 peças de cerâmica comum, que indiciam uma diminuição da produção Bética para $45 \%$, um aumento da cerâmica local/regional de pasta cinzenta para 14\% (produção máxima alcançada nas três fases por este tipo de produção aqui representadas pela tampa ou a caçoila de bordo escalonado), e uma ligeira variação relativamente à fase $1(21 \%)$ da cerâmica local de pasta laranja. O consumo de cerâmica de cozinha originária da Africa Proconsular, representada pelas formas Hayes 196, Hayes 197, Hayes 23 B e Hayes 181, aumentou significativamente de $3 \%$ para $17 \%$, (Viegas e Arruda, 2014, 255-257).

Por último, no momento final da ocupação e abandono das estruturas do Sector A, as UEs 28, $29,36,55$ e 59 foram datadas dos meados/terceiro quartel do século II (Viegas e Arruda, 2014, 257). Nesta terceira fase, as produções importadas do Norte de África passaram a dominar, com um peso de $56 \%$. As produções locais de pasta laranja, apesar de manterem a sua proporção no conjunto (21\%), aumentaram significativamente o seu número, passando dos 28 da primeira fase e 51 da segunda para os 369 exemplares nesta. Este aumento deveu-se à utilização dos quatro fornos cerâmicos cronologicamente datados desta época. Refira-se ainda que, nesta fase, a cerâmica regional de pasta cinzenta manteve sensivelmente o mesmo número de exemplares produzidos na fase anterior (35-36), mas passou a corresponder apenas a $2 \%$ do total, face ao aumento dos restantes tipos (Viegas e Arruda, 2014, 257).

As unidades estratigráficas com maior volume de indivíduos de cerâmica de Cozinha Africana foram as UE 85 (457 NMI), UE 28 (236 NMI) e a UE 55 (227 NMI), correspondentes à fase 3 momento final de ocupação / - abandono.

Dos espólios recolhidos em contextos seguros nas áreas residenciais, verifica-se, assim, a supremacia numérica desta categoria de cerâmica comum entre o número de indivíduos de cerâmica de cozinha africana (1035) e o das produções béticas (525) (particularmente as da baía de Cádis) em relação à cerâmica de produção local de pasta cor laranja (448).

No sector C, não foi possível localizar ainda qualquer estrutura habitacional da época romana imperial (Arruda, et al., 2008). No entanto, foram aí identificados quatro fornos cerâmicos, que justificam o aumento de produção local de cerâmica com pasta laranja na terceira fase, conforme referido anteriormente, o que, aliás, contribuiu para considerar este Sector como "área de produção industrial”, para a época romana imperial. Ainda assim, foi possível determinar a existência de três fases distintas de construção/utilização destas 
estruturas de produção cerâmica, que se sucedem no tempo.

Os fragmentos pertencentes a vasos de uso comum aqui encontrados correspondem, na sua maioria, à produção local. Contudo, a cerâmica de cozinha africana está presente, representada por 52 NMI, maioritariamente das formas dominantes no sítio: prato/tampa Hayes 196(25 NMI), tacho Hayes 197 (8 NMI) e caçoila 23B (9 NMI) (elementos recolhidos em contexto primários de ocupação).

A associação das cerâmicas de cozinha africana à terra sigillatta permitiu precisar a cronologia das três fases acima referidas. Na primeira, dominavam as produções de terra sigillata do sul da Gália e as formas de cozinha africana Hayes 196 e Hayes 197; na segunda, um exemplar de terra sigillatta de Clara A da forma Hayes 6 (fim do século I e início de século II) e três da forma Hayes $8 \mathrm{~A}$ (segunda metade do século II) (Bonifay, 2004, 156). A identificação da terceira fase baseou-se nas formas mais tardias da terra sigillatta Clara A. A inexistência de tipos de terra sigillatta Clara A datáveis do século III, indicia o fim da produção na segunda metade do século II (Arruda, Viegas e Bargão, 2010, 303).

\subsection{A CERÂMiCA AFrica DE COZINHA DE MONTE} MOLIÃO: SÍNTESE DOS RESULTADOS

A cerâmica de cozinha africana de Monte Molião deve ainda ser interpretada num contexto mais vasto que tenha em consideração a própria dinâmica importadora do sítio ao longo da diacronia, e as suas relações "comerciais" com outras áreas do Império.

Em primeiro lugar, ficou claro que na terceira e última fase de ocupação de Monte Molião as importações de produções tunisinas passaram a dominar na cerâmica comum, substituindo as cerâmicas béticas que, em fases anteriores, se impunham às restantes (Fig. 12). A produção local, embora tivesse aumentado na fase final devido à construção dos fornos identificados no Sector C, nunca conseguiu produzir o suficiente de modo a tornar a comunidade auto-suficiente no que ao abastecimento de cerâmicas para uso comum diz respeito, mesmo que, como se sabe, algumas formas de cerâmica de cozinha africana tenham sido reproduzidas nesses mesmos equipamentos (Viegas e Arruda, 2014).

Deve ainda referir-se que, no que se refere à cerâmica comum, se verificam claras distinções que importa aqui apresentar. Assim, e tal como já foi notado antes (Viegas e Arruda, 2014), torna-se evidente que as importações do Norte de Africa se relacionam com processos culinários a quente; tachos, caçoilas e pratos/tampa, muito provavelmente pela sua resistência do fogo. Por outro, da Bética, as formas mais procuradas eram as tigelas, pequenas bilhas, almofarizes, potes, alguidares e grandes recipientes, eventualmente de armazenagem. Neste caso concreto, o facto de as pastas calcárias não terem resistência ao calor justificará esta situação. O conjunto cerâmico local/ regional incorporava, essencialmente, potes, copos, pratos, tampas e jarros, donde se conclui que as produções oriundas da Bética, bem como o que era manufacturado localmente ou na região, eram as formas mais vocacionadas para os processos culinários a frio (Arruda, Viegas e Bargão, 2010). Esta realidade leva-nos a acreditar que não era a aparência estética que era valorizada pela população do Monte Molião, mas sim a sua utilidade na exposição ao fogo ou na funcionalidade no serviço de cozinha.

Tal como se referiu já anteriormente, a maioria dessas cerâmicas foi recolhida em áreas residenciais descobertas no sector A. É também de realçar o facto de ter sido nas UEs da terceira e última fase, que se encontrou o maior volume de indivíduos, que, aliás, ajudaram a datar o momento final da ocupação e de abandono das estruturas do sector A.

Não pode também deixar de se referir neste contexto, que a cerâmica de cozinha africana reflecte uma realidade muito particular no que se refere às próprias importações e relações comercias com o norte de África. De facto, constata-se aqui que esta categoria cerâmica representa um importante papel nestas últimas, uma vez que se constitui como o grosso das importações. Com efeito, e ainda que a terra sigillata africana (Clara A) esteja presente, as quantidades são muito reduzidas (58 NMI), não sendo comparáveis às da cerâmica comum com a mesma origem. Por outro lado, as importações anfóricas norte-africanas estão ausentes nestas cronologias, apesar de nas fases mais antigas elas terem sido documentadas, concretamente através de exemplares enquadráveis nos tipos Maña C1, Maña C2a e Tripolitanas Antigas (Arruda e Sousa, 2010). Assim, e ao contrário do que se poderia numa primeira leitura pensar, a cerâmica de cozinha africana não se constitui, pelo menos nestas primeiras fases de produção e exportação, como uma importação subsidiária da cerâmica de mesa. Pelo contrário, trata-se de uma cerâmica valorizada de per se. 
3. A CERÂmica de cozinha africana de Monte Molião NO SEU CONTEXTO REGIONAL E SUPRA REGIONAL

Em primeiro lugar, cabe destacar que se os dados abundam para o sul, a realidade do litoral ocidental é bem diferente, sendo evidente a sua escassez nesta última região. Este facto tornar-se-ia ainda mais evidente se aos dados numéricos juntássemos os de ordem cronológica. Com efeito, a cerâmica de africana cozinha está, no Algarve, concretamente em Monte Molião, mas também em Cerro da Vila (Teichner, 2008), e quase seguramente em Ossonoba (Viegas, 2008), datada de um momento antigo ainda do Alto Império. Pelo contrário em Tróia (Magalhães, Brum e Pinto, 2014), Ilha do Pessegueiro (Silva e Soares, 1993) e São Cucufate (Pinto, 2003) estes materiais estão associados a ocupações dos séculos III a V.

Mas não devemos perder de vista, que as comparações que aqui efectuámos estão também limitadas pelo facto de lidarmos com dados diversos no que diz respeito à sua recolha: uns são provenientes de escavações arqueológicas mais ou menos extensas (por exemplo, Monte Molião, Cerro da Vila (Teichner, 2008), Ossonoba (Viegas, 2008), Balsa (Viegas, 2011), São Cucufate (Pinto, 2003), enquanto outros provêm de trabalhos de prospecção, como é o caso do Vidigal (Pereira, 2012).

Ainda assim, parece relevante deixar claro que as formas minoritárias Ostia I (261 e 264), II (306, 310, 312 e 314), Sidi Jdidi e os Jarros/Fervedores são, no território actualmente português, exclusivos do Monte Molião, com excepção da Ostia I/261, representada também na Ilha do Pessegueiro (Silva e Soares, 1993). Naturalmente que esta situação pode explicar-se pela carência de estudos da natureza deste que agora publicamos.

Relativamente às formas maioritárias, destacase em Monte Molião, bem como, aliás, em todos os restantes sítios portugueses, a 197 de Hayes. No Algarve, os tachos de cerâmica de cozinha africana deste tipo estão presentes em Vila Velha de Alvor (onde são exclusivos, nesta categoria cerâmica) e Vale da Arrancada (Portimão) (materiais ainda inéditos), mas também em Ossonoba (Viegas, 2008), Balsa (Viegas, 2011), Quinta de Marim (Silva, Soares e Coelho-Soares, 1992), Cerro da Vila (Teichner, 2008) e Vidigal (Pereira, 2012). Em todos os restantes sítios, a mesma forma foi registada.

A realidade é idêntica para os pratos/tampas da forma Hayes 196, sendo, aliás, evidente a relação entre ambos os tipos. Neste caso, a forma está apenas ausente em Alvor, onde como já se referiu a única forma documentada é a 197.

A mesma situação quanto às presenças/ausências é verificável para a caçoila Hayes 23, inexistente em São Cucufate (Pinto, 2003), na Quinta de Marim (Silva, Soares e Coelho-Soares, 1992) e, evidentemente, em Alvor.

O panorama que pudemos traçar das importações de cerâmica de cozinha africana em Monte Molião em particular e no Algarve em geral pode, e deve, ser também explicado num quadro mais global, concretamente o do Sul da Península Ibérica.

E pode afirmar-se desde logo que quer em termos cronológicos quer no que diz respeito aos aspectos formais as realidades litorais peninsulares não se diferenciam substancialmente. De facto, o sul da Lusitânia importou, a partir do reinado dos flávios as mesmas cerâmicas para utilizar na cozinha, sobretudo ao lume, que a Bética e a Tarraconense.

Os dados estratigráficos e contextuais de Monte Molião comprovam, sem margem para qualquer dúvida, que as primeiras importações desta categoria cerâmica chegaram ao Algarve ocidental ainda na segunda metade do século I, tendo-se prolongado por todo o século II, onde, aliás abundam. Parece fazer sentido recordar de novo aqui que a grande maioria da cerâmica de cozinha africana encontrada em Monte Molião foi recuperada nos níveis correspondentes à última fase de ocupação do sítio e nas UEs identificadas como de abandono, das últimas décadas do século II.

Também no Cerro da Vila as mesmas associações de materiais puderam ser verificadas, o que indicia idênticas cronologias e formas semelhantes (Teichner, 2008).

Infelizmente, não existem dados que possam comprovar a mesma situação em Balsa, onde a cerâmica de cozinha africana é abundante, mas cujos contextos são inexistentes. Para Ossonoba, concretamente na área do mosaico do Oceano, tudo indica haver importações pelo menos desde o século II (Viegas, 2008). Esta antiguidade da produção e exportação da cerâmica de cozinha africana foi igualmente provada em outros locais peninsulares, como é por exemplo o caso de Carmona (Vázquez Paz, 2006), de Córdova (Monterroso Checa, 2002), de Tarraco (Ruiz Arbulo et al., 2010), de Guadix (Doblas Peguero, 2013) e de Valência (Ribera i Lacomba, 2010), entre vários outros centros de consumo. Igualmente em qualquer destes casos 
a cronologia foi claramente aferida por materiais datantes, como por exemplo a terra sigillata.

A escassez de terra sigillata hispânica em Monte Molião poderia ter implicado o domínio dos produtos de mesa oriundos do norte de África. Porém, a sigillata africana A é também insignificante em termos numéricos, o que valoriza um tipo de relações comerciais com o norte de África baseado numa categoria cerâmica considerada de baixo valor comercial.

A "litoralização" das importações destes produtos manufacturados deve, portanto, frisarse, ainda que, em alguns casos, sobretudo do actual território espanhol, a interioridade deva ser desvalorizada, porque o acesso a esses sítios estava facilitado pela existência de rotas fluviais.

No Monte Molião, com uma fundação anterior à época romana (Arruda et al., 2014), a ocupação romana fez-se sentir de forma intensa logo desde o período republicano (Arruda e Sousa, 2010). A sua posição geográfica, no litoral, mas com acesso fácil ao interior através da Ribeira de Bensafrim ofereceu-lhe condições privilegiadas.

Em ambas as margens do estuário da Ribeira de Bensafrim foram identificadas várias estruturas destinadas ao processamento de produtos de origem marinha - na margem esquerda, Monte Molião (Bargão, 2008), na direita, sob a actual cidade de Lagos, (Ramos, Almeida e Laço, 2006). O dinamismo destas "indústrias" desenvolveu necessariamente outras actividades, podendo conjecturar-se a construção naval, o fabrico de redes, a produção de anzóis (Lourenço, 2012) e até a de contentores para colocar o produto final.

Não é, pois, impossível pensar que o "lucro" obtido nessas actividades permitia à comunidade local adquirir ou trocar produtos provenientes do Mediterrâneo por via marítima, apesar de sabermos que a integração do Sul da Lusitânia no mundo provincial romano também sugere que algumas presenças possam ser explicadas num quadro de puro e simples "abastecimento".

Todo este contacto, com a consequente utilização de produtos manufacturados e alimentares, bem como outros factores, concretamente a própria origem geográfica e social dos vários elementos da população, tiveram consequências a diversas escalas, como é o caso dos próprios hábitos alimentares, que puderam também ser avaliados pelo estudo que efectuámos sobre a cerâmica de cozinha africana. Fica evidenciado que mesmo que os fritos tenham sido introduzidos, massivamente, na época romana, os cozidos e, sobretudo, os estufados permaneceram como os processos dominantes na confecção dos alimentos. Lembre-se que a caçoila e a panela são as formas maioritárias quer em Monte Molião quer nos restantes sítios peninsulares e extra-peninsulares. Mas o prato/tampa, também tão abundante, indicia que os alimentos sólidos começaram a ser consumidos de forma mais habitual, ao contrário do que se passava em época pré-romana, onde as tigelas dominavam em absoluto (Sousa e Arruda, 2010).

Entre a época Flávia e os meados/terceiro quartel do século II, e a julgar pelos dados que o sítio já forneceu, Monte Molião viveu o seu apogeu, tendo a ligação ao Mediterrâneo permitido contactos comerciais estruturados e lucrativos. A aproximação à rota marítima que ligava o mundo oriental ao Ocidente possibilitou a troca, venda ou aquisição de produtos com as comunidades mediterrâneas, fornecendo-lhe uma importância estratégica que valorizava o sítio face às demais regiões do interior e mesmo da costa ocidental.

Esta navegação entre o Mediterrâneo e o Atlântico é referida em fontes literárias (Élio Aristides, meados do século II): "São muitos os que agora navegam para além das Colunas de Hércules. Sem dúvida alguma em número não menor que noutros tempos. E não um ou dois barcos num amplo lapso de tempo, senão que em cada dia os transportes e os mercadores passam de uma a outra parte do mar, como se fosse um só, já que aquela parte (Atlântico) está totalmente aberta e existe uma grande segurança na navegação devido à nossa hegemonia"(Mantas, 1998, 212).

A presença em abundância da cerâmica de cozinha africana, originária da actual Tunísia, no Monte Molião, permitiu-nos aprofundar o conhecimento acerca das práticas sociais, dos hábitos de consumo e do comércio marítimo.

Se por um lado se tornou claro que a população local foi alterando as suas práticas sociais e os seus hábitos de consumo, também parece evidente que o comércio sofreu uma tendência litoralizante (devido não só à concorrência externa como à evolução das elites locais que o controlavam (Mantas, 1998, 221), tornando-se um essencialmente marítimo. 


\section{Bibliografia}

Aguarod Otal, C. (1991), Cerámica romana importada de cocina en la Tarraconense, Institución "Fernando el Católico", Zaragoza, 17-629.

Albiach, R., Marín, C., Pascual, G., Pià, J., Ribera, A., Rosselló, M., Sanchis, A. (1998), "La cerámica de época de augusto procedente del relleno de un pozo de valentia (Hispania tarraconensis)", S.F.E.C.A.G., Congrès d'Istres, 139-166.

Álvarez, N., Balleste, C., Espí, I., Mañez, J., Marín, C., Pascual, G., Ribera, A., Rosselló M. (2003) "las cerámicas de tres nuevos depósitos votivos de fundación de las excavaciones de l'almoina (valencia)”, S.F.E.C.A.G., Congrès de Vienne, 369-396.

Aquilué Abadías, X. (1995), "La cerámica común africana. Cerámica comuna romana d'época Alto-Imperial a la Península Ibèrica. Estat de la qüestió", Ceràmica comuna romana d'època altoimperial a la Peninsula Ibèrica. Estat dela questió (M. Roca e X. Aquilué, Coords.), Monografies Emporitanes VIII, 61-74.

Arnau Davó, M., García Villanueva, M. I., Ruiz Val, E., e Serrano Marcos, M. L. (2003), "El monumento funerario templiforme de la plaza de San Nicolás, Valencia, y su contexto arqueológico", Saguntum, 35, 177-195.

Arruda,A.M.(2007), "Laccobriga e o seu território”, Laccobriga. A ocupação romana na Baía de Lagos, Lagos, Câmara Municipal, 7-47.

Arruda, A. M. e Pereira, C. (2010), "Fusão e produção: actividades metalúrgicas em Monte Molião (Lagos) durante a época romanorepublicana", Xelb, 10, 695-716.

Arruda, A. M. e Sousa, E. (2010), “Ânforas republicanas de Monte Molião (Lagos, Algarve, Portugal)”, Spal, 21, 93-133.

Arruda, A. M., Sousa, E., Bargão, P., e Lourenço, P. (2008), "Monte Molião(Lagos): resultados de um projecto em curso", Xelb, 8/1, 137-168.

Arruda, A. M., Sousa, E., Pereira, C., e Lourenço, P. (2014), "Monte Molião: um sítio púnicogaditano no Algarve (Portugal)", Conímbriga, 50, 5-32.

Arruda, A. M., Viegas, C., e Bargão, P. (2010), “A cerâmica comum de produção local de Monte Molião", Xelb, 10, 285-304.

Bargão, P. (2008), "intervenção de emergência no Monte Molião: primeiras leituras” Xelb, 8, 169190.
Batigne, C. e Desbat, A. (1996), "Un type particulier de "cruche": Les bouilloires en céramique d'époque romaine (Ier-IIIe siècles)“, SFECAG, Actes du Congrés de Dijon, 381-394.

Bernal, D., Arévalo, A., Lorenzo, L., e Cánovas, A. (2007), "Abandonos en algunas insulae del barrio industrial a finales del siglo II d.C.”, Las cetariae de Baelo Claudia (A. Arévalo e D. Bernal, Eds.), Cádiz, Universidad de Cádiz, 385-571.

Blázquez Martínez, J. (2002), "El comercio de cerámicas del Norte de África y del Oriente con Hispania en la Antigüedad Tardía”, Estudios sobre el Monte Testaccio (Roma), III (J.M ${ }^{a}$ Martínez Blázquez e J. Remesal, Eds.), Montagnac, 567-607.

Bonifay, M. (2004), Études sur la céramique romaine tardive d'Afrique, BAR International Series, 1301, Oxford.

Carrillo Díaz-Pinés, J. R. e Murillo Redondo, J. F. (1996), "Um vertedero con cerámica africana de cocina em Colonia Patricia", Africa Romana (Atti dell XI convegno di studio Cartagine, 15-18, Dicembre 1994), 1301-1319.

Casas, J e Nolla, J. (1986-1989): "Un conjunt tancat amb cerámica africana a la villa romana dels $T o$ legassos (Viladamat. Alt Empordá), Empúries 48-50 I, 202-213.

Doblas Peguero, V. (2013), "La cerámica africana de cocina de Guadix (Granada). La excavación del Callejón Atahona”, Bastetania, 1, 31-37.

Gómez Bravo, M. e Miñano Domínguez, A. (1999) "Excavación arqueológica de urgência em dos solares de la calle Valle de Húcal (La Azohía, Cartagena”, Memorias de Arqueología, Región de Múrcia, 14, 315-330.

Hayes, J. W.(1980), A Supplement to Late Roman Pottery, The British School at Rome, London.

Hayes, J.W. (1972), Late Roman Pottery. A Catalogue of Roman Fine Wares, The British School at Rome, London, 198-215.

Huguet Enguita, E. (2009), "Material cerámico de la villa romana de La Vallaeta M15.3”, Arse, 43, 63-159.

Járrega Domínguez, R. (2008), La Villa romana del Mas d'en Gras (Vila-seca, Tarragonès), Institut Català d'Arqueologia Clássica, Tarragona.

Jordá, C. M. (1995), "La cerámica de cocina africana: consideraciones en torno a la evidencia Valenciana”, Ceràmica comuna romana d'època altoimperial a la Peninsula Ibèrica. 
Estat dela questió (M. Roca e X. Aquilué, Coords.), Monografies Emporitanes, VIII, 155165.

Lourenço, P. (2012), A pesca na Antiguidade: o caso de Monte Molião (Lagos), Dissertação de Mestrado apresentada à Faculdade de Letras da Universidade de Lisboa, Policopiado.

Magalhães, A. P., Brum, P. e Pinto, I. V. (2014), "The significance of african cooking ware in Lusitânia: The case of Tróia (Portugal)", Rei Cretariae Romanae Favtorum Acta, 43, 701708.

Mantas, V. (1998), "Navegação, economia e relações interprovinciais. Lusitânia e Bética”, Humanitas, 50, 199-239.

Marin jordá, C. (1995), "La cerámica de cocina africana: Consideraciones en torno a la evidencia valenciana", Ceràmica comuna romana d’època alto-imperial a la Península Ibèrica. Estat de la qüestió (M. Roca e X. Aquilué, Coords.), Monografies Emporitanes VIII, 155165.

Monterroso Checa, A. (2002), "Cerámica Africana en Colónia Patrícia: Aportaciones a partir de la estratigrafia del Teatro Romano de Córdoba. La Terraza Media Oriental", Romvla, 1, 187224.

Moreno Almenara, M., Murillo Redondo, J. F., Ruiz Lara, M. D., Carrillo Díaz Pinés, J.R., Carmona Berenguer, S., González Vírseda, M. L., e Vargas Cantos, S. (2003), "Resultados de la intervención arqueológica de urgencia realizada en el Callejón del Galápago de Córdoba (1998-1999)" Anuario Arqueológico de Andalucía/2000, III/1, 410-462.

Nieto, F.J. (1993), El edificio A de la ciudadela de Roses. La Terra Sigillata Africana. Gerona.

Nolla, J.M. e Casas, J. (1990), "El materiaI ceràmic d'impotació de la villa romana de Puig Rodon (Corçà, Baix Empordà), d'època severiana a la Baixa Antiguitat”, Cypsela, 8, 193-218.

Pereira, C. (2012), "O sítio romano do Vidigal, Aljezur”, Revista Portuguesa de Arqueologia, 15, 155-179.

Pinto, I. (2003), A Cerâmica Comum das Villae Romanas de São Cucufate (Beja), Lisboa.

Quaresma, J. C. (1999), "Terra sigillata africana, hispânica, foceense tardia e cerâmica africana de cozinha de Mirobriga (Santiago do Cacém)”, Conimbriga, XXXVIII, 137-200.

Quaresma, J. C.(2012), Economia Antiga a partir de um centro de consumo lusitano. Terra sigillata e cerâmica africana de cozinha em Chãos Salgados (Mirobriga?), Estudos e Memórias 4, Lisboa.

Ramos, A C., Almeida, R. e Laço, T. (2006), "O Complexo Industrial da Rua Silva Lopes (Lagos). Uma primeira leitura do sítio e análise das suas problemáticas no quadro da indústria conserveira da Lusitânia meridional”, Setúbal Arqueológica, 13, 83-100

Ribera I Lacomba, A. (2010), "Los materiales de época augustea de Valentia: símbolo de una etapa precaria o muestra del inicio del renacer de la ciudad", Contextos ceràmics i cultura material d'època augustal a l'occident romà (V. Revilla Calvo e M. Roca Roumens, Coords.), Barcelona, 262-293.

Roca Roumens, M. e Fernandez García, M. I. (2005), Introdución al estúdio de la cerâmica romana: un breve guía de referencia. Málaga

Ruiz Arbulo, J., Mar, R., Roca, M. e Diaz, M. (2010), "Un contexto cerámico de fines del siglo I a.C. como relleno constructivo de un almacén portuario localizado bajo el teatro romano de Tarragona", Contextos ceràmics i cultura material d'època augustal a l'occident romà (V. Revilla Calvo e M. Roca Roumens, Coords.), Barcelona, 222-261.

Salomonson, J. W. (1970), "La céramique”, La nécropole romaine de Raqqada (A. Mahjoubi, J. W. Salomonson e A. Ennabli Coords.), Tunis, 22-81.

Sánchez Martín, M. (2003), "Estudio de las estructuras y de los materiales altoimperiales de la c/ mayor, 4 Sagunto (Valencia)”, ARSE, 37, 37-63.

Sánchez Martín. A. (1995), "Producciones importadas en la vajilla culinaria romana del Bajo Guadalquivir", Ceràmica comuna romana d'època alto-imperial a la Península Ibèrica. Estat de la qüestió ( $M$. Roca e X. Aquilué, Coords.), Monografies Emporitanes VIII, 251-280.

Serrano Ramos, E. (2000), “Cerámica común romana: siglos II a.C. al VII d.C. Materiales importados y de producción local en el territorio malacitano, Málaga.

Silva, C. e Soares, J. (1993), Ilha do Pessegueiro. Porto Romano da Costa Alentejana, Instituto da Conservação da Natureza, Lisboa.

Silva, C., Soares, J. e Coelho-Soares, A. (1992), "Estabelecimento de produção de salga de peixe 
de época romana na Quinta de Marim (Olhão). Resultados preliminares das escavações de 198889”, Setúbal Arqueológica, 9-10, 335-374.

Sousa, E. e Arruda, A. M. (2014), "A cerâmica comum romano-republicana de Monte Molião (Lagos)”, Onoba, 2, 55-91.

Sousa, E. e Arruda, A.M. (2010), “A gaditanização do Algarve” Mainake, 32 (2), 951-974.

Teichner, F. (2008), Zwischen Land und MeerEntre tierra y mar. Studien zur Architektur und Wirt - schaftsweise ländlicher Siedlungen im Süden der römischen Provinz Lusitanien, Studia Lusitana, 3, Museu Nacional de Arte Romano, Mérida.

Tortorella, S. (1981a), "Ceramica da cucina”, Atlante delle forme ceramiche, I, Enciclopédia dell'Arte antica e orientale, Intituto dela Enciclopedia Italiana, Roma, 208-227.

Tortorella, S. (1981b), "Ceramica di produzione africana e rinvenimenti archeologici sottomarini della media e tarda età imperiale: Analisi de i dati contributi reciproci”, Mélanges de l'École Française de Rome-Antiguité, 93, 355-380.

Vargas Cantos, S. (2000) - "El vicus occidental de Colonia Patricia. Bases para su estudio: la cerámica romana”, $A A C, 11,177-201$.

Vásquez Paz, J. (2006), "Contextos ceramológicos de la Carmona romana altoimperial”, Carel, 4, 1611-1670.

Viegas, C. (2008), "O mosaico do Oceano (Faro) cerâmicas associadas", Actas do IV Congresso de Arqueologia Peninsular, Promontoria Monográfica 10, Faro, 197-214.

Viegas, C. (2011), A ocupação romana do Algarve estudo do povoamento e economia do Algarve central e oriental no período romano, Estudos e Memórias, 3, Lisboa.

Viegas, C. e Arruda, A. M. (2014), "A cerâmica de cozinha africana e as suas imitações em Monte Molião (Lagos, Portugal)", As produções cerâmicas de Imitação na Hispânia (R. Morais, A. Fernández e M.J. Sousa, Eds.), Monografias Ex Officina Hispana, II, Tomo I, 247-260. 
